\title{
Optimization of a Novel Alkaline Protease from Cashew Industrial Soil Associated Aspergillus niger
}

\author{
G. Parvathy*, C. Prabhakumari, Nair Sreecha Chandran and Sonia John \\ Department of Biotechnology, CEPC Laboratory and Research Institute, \\ Mundakkal, Kollam, Kerala, India \\ *Corresponding author
}

\section{A B S T R A C T}

Protease the leading industrial enzyme accounts for about $60 \%$ of the total enzyme market. It has wide application in different sectors. The search of proteases with better activity and

Keywords

Protease, Aspergillus niger, NFCCI.

Article Info

Accepted:

26 October 2017

Available Online:

10 December 2017 potential of different application is very important. The current paper screened cashew nut processing units' soil near Kollam for the isolation of effective protease producers. The isolated fungal strains isolated from soil by serial dilution method were screened by casein hydrolysis for alkaline protease production. Out of the ten isolated strains of fungi A, B, G and $\mathrm{H}$ are protease producers. After the optimization the isolate strain $\mathrm{H}$ showed highest activity in the optimized medium at $\mathrm{pH} 11.0$, temperature $35^{\circ} \mathrm{C}$, with glucose as carbon source incubated for 7 days. The highest enzymatic activity is showed in the 4th day of batch fermentation at $96 \mathrm{hr}$ of incubation. The most potent protease produced strain was identified based on morphological characterization characteristics in National Fungal Culture Collection of India (NFCCI \& FIS) Pune as Aspergillus niger. Proteases represent one of the largest groups of industrial enzymes and find application in detergents in the removal of different kinds of stains and also in dehairing process practised in leather industry.

\section{Introduction}

Proteases catalyze hydrolytic reactions of protein molecules resulting the formation peptides and amino acids. These enzymes have remarkable applications in both physiological and commercial fields. Among all the different commercial enzymes, microbial protease in particular, represents about $60 \%$ of all the industrial enzyme's sales in the world due to their applications in several industrial sectors like in the detergent, food, pharmaceuticals, chemicals, leather, paper and pulp and silk industries (Singh et al., 2016). Proteases have physiological role in all living organisms and therefore, they are present in a wide range of sources such as animals, plants and microorganisms (Rao, 1998) Microbial origin proteases are preferred over other proteases for industrial application due to the broad biochemical diversity and their susceptibility to genetic manipulation as well as economic advantages (Souza et al., 2015; Ferid Abidi et al., 2008).

The protease mediated leather processing is an efficient alternative in an environmental friendly manner to improve the quality of leather, help to shrink waste and, save time and energy (Zambare et al., 2011; Adrio and 
Demain, 2014). This paper reports the isolation characterization and optimization of a novel extracellular alkaline protease from Aspergillus niger that has an wide application in different industry.

\section{Materials and Methods \\ Isolation of protease producer from soil sample}

Soil samples were collected from Cashew Industry near Kollam. Enrichment method was done for that all the soil samples were pooled and inoculated in to protease producing media containing the following: $(\mathrm{g} / \mathrm{L})$ glucose $5.0 ;$ peptone $7.5 ; \mathrm{MgSO}_{4} 7 \mathrm{H}_{2} \mathrm{O}$ 5.0, $\mathrm{KH}_{2} \mathrm{PO}_{4}$ 5.0, and $\mathrm{FeSO}_{4} 7 \mathrm{H}_{2} \mathrm{O} 0.1$ and incubated for 48 hours at $37^{\circ} \mathrm{C}$ for isolating efficient protease producers. After the incubation the sample was plated in to Casein agar plates at $\mathrm{pH} 7$. The protease production was confirmed by the formation of clear zones around the colonies. The individual isolates which show clear zone was selected and grown in $100 \mathrm{ml}$ of protease producing media the protease that released in to the fermentation media was quantitatively measured Sigma-Aldrich method.

\section{Protease assay}

The protease activity was determined by the Sigma-Aldrich method. The reaction mixture contains $450 \mu \mathrm{l}$ of $1 \%$ casein in $50 \mathrm{mM}$ phosphate buffer ( $\mathrm{pH} \mathrm{7)}$ and $50 \mu \mathrm{l}$ of the enzyme. After $20 \mathrm{~min}$ incubation at $37^{\circ} \mathrm{C}$ the reaction was stopped by adding $750 \mu \mathrm{l}$ of TCA solution followed by $30 \mathrm{~min}$ incubation at room temperature and centrifugation (15000 x g, 15 min).

In $2 \mathrm{ml}$ above filtrate after centrifugation, 5 $\mathrm{ml}$ of $0.4 \mathrm{M}$ sodium carbonate and $1 \mathrm{ml}$ of Folin's reagent was added, mixed and incubated at $37^{0} \mathrm{C}$ for 30 minutes. The developed blue colour was read at $660 \mathrm{~nm}$ One unit of the enzyme activity was defined as the amount of enzyme which releases 1 $\mu$ mol of tyrosine per min under the assay conditions.

\section{Optimisation studies on protease production}

\section{Effect of pH on protease production}

The effect of $\mathrm{pH}$ on alkaline protease production by the fungi was determined by growing the isolates in assay medium with different alkaline $\mathrm{pH}$ in the range of 4-11 using required concentrations of $1 \mathrm{~N} \mathrm{NaOH}$ and $1 \mathrm{~N} \mathrm{HCl}$. Protease activity was determined in the supernatant.

\section{Effect of incubation temperature on protease production}

The effect of temperature on protease production by the fungi was determined by growing it in assay media at different temperatures $\left(25-40^{\circ} \mathrm{C}\right.$ with an interval of $50^{\circ} \mathrm{C}$ ) with the $\mathrm{pH}$ and time of incubation remains constant at 11 and $24 \mathrm{hr}$ respectively. The protease assay was carried out to determine the concentration of the enzyme.

\section{Effect of different carbon source on protease production}

The effect of various simple carbon sources such as glucose, sucrose and lactose on the production of alkaline protease by fungi was studied.

These carbon sources were added individually in the production medium at different concentration of $0.5-10 \%(\mathrm{w} / \mathrm{v})$. The $\mathrm{pH}$, temperature and incubation time of the medium was set at 11.0 at $37^{\circ} \mathrm{C}$ for $24 \mathrm{hr}$, respectively. 
Effect of different incubation period on protease production

To study the effect of time for optimization of protease production, the isolate was inoculated in to the assay medium with $\mathrm{pH} 11$. Further, the organism was incubated at $37^{\circ} \mathrm{C}$ in shaker to obtain a uniform growth. The alkaline protease activity was monitored at regular time intervals of $24,48,72$ and 96 hour's duration.

\section{Identification of isolate}

The isolate which show maximum enzyme production was sent to National Fungal Culture Collection of India (NFCCI \& FIS) Pune for morphological identification.

\section{Results and Discussion}

\section{Isolation of protease producer from soil sample}

Screening of protease producing microorganisms usually involves growth on the medium that contains protein as the selective substrate. The growth of microorganisms on skim milk agar was tested (Sharma et al., 2006). Following inoculation and incubation of the agar plate cultures, organisms secreting proteases, exhibited a zone of proteolysis, which was demonstrated by clear area surrounding the microorganism's growth. This zone of protease is a result of a hydrolytic reaction yielding soluble, non-colloidal amino acids and it represents a positive reaction. In the absence of protease activity, the medium surrounding the growth of the organism remains opaque, which is a negative reaction (Cappuccino and Sherman, 2002). In this present investigation, skimmed milk powder was used as the selective substrate, in which the isolated organisms were streaked. The fungal strain $\mathrm{A}, \mathrm{B}, \mathrm{G}, \mathrm{H}$ produced clear zone in the media the protease producing strains with $25-40 \mathrm{~mm}$ diameter of proteolytic zone were characterized and hence was confirmed to be protease producers.

\section{Isolation of protease producer from soil sample}

Soil samples were collected from Cashew Industry near Kollam. Enrichment method was done for that all the soil samples were pooled and inoculated in to protease producing media containing the following: $(\mathrm{g} / \mathrm{L})$ glucose 5.0; peptone 7.5; $\mathrm{MgSO}_{4} 7 \mathrm{H}_{2} \mathrm{O}$ 5.0, $\mathrm{KH}_{2} \mathrm{PO}_{4}$ 5.0, and $\mathrm{FeSO}_{4} 7 \mathrm{H}_{2} \mathrm{O} 0.1$ and incubated for 48 hours at $37^{\circ} \mathrm{C}$ for isolating efficient protease producers. After the incubation the sample was plated in to Casein agar plates at $\mathrm{pH}$ 7.The protease production was confirmed by the formation of clear zones around the colonies. The individual bacterial isolates which show clear zone was selected and grown in $100 \mathrm{ml}$ of protease producing media the protease that released in to the fermentation media was quantitatively measured Sigma-Aldrich method.

\section{Protease assay}

The protease activity was determined by the Sigma-Aldrich method. The reaction mixture containing $450 \mu \mathrm{l}$ of $1 \%$ casein in $50 \mathrm{mM}$ phosphate buffer $(\mathrm{pH} \mathrm{7)}$ and $50 \mu 1$ of the enzyme. After $20 \mathrm{~min}$ incubation at $37^{\circ} \mathrm{C}$ the reaction was stopped by adding $750 \mu \mathrm{l}$ of TCA solution followed by 30 min incubation at room temperature and centrifugation (15000 x g, $15 \mathrm{~min})$. In $2 \mathrm{ml}$ above filtrate after centrifugation, $5 \mathrm{ml}$ of $0.4 \mathrm{M}$ sodium carbonate and $1 \mathrm{ml}$ of Folin's reagent was added, mixed and incubated at $37^{\circ} \mathrm{C}$ for 30 minutes. The developed blue colour was read at $660 \mathrm{~nm}$. One unit of the enzyme activity was defined as the amount of enzyme which releases $1 \mu \mathrm{mol}$ of tyrosine per min under the assay conditions. 
Optimisation studies on protease production

\section{Effect of $\mathrm{pH}$ on protease production}

Among physical parameters, $\mathrm{pH}$ of the growth medium plays an important role by inducing morphological changes in microbes and in enzyme secretion. The $\mathrm{pH}$ change observed during the growth of microbes also affects product stability in the medium. The optimal $\mathrm{pH}$ varies with different microorganisms and enzymes. All the four isolates were allowed to grow in media of different $\mathrm{pH}$ ranging from7.0 to 11.0. Maximum enzyme activity was observed in medium of $\mathrm{pH} 11.0$ in case of strain $\mathrm{H}$. It has been reported widely that protease production from microbial source can be acidic or alkaline proteases as reported by many researchers depending on the organisms and source of the isolation.

Among the four fungal strains A, G, H shows high protease activity and hence undergoes the large scale production of these strains at optimized pH 11 (Sookkheo et al., 2000) also reported the optimum $\mathrm{pH}$ for protease activity to be between 7.0 and 8.5 (Borris, 1987) reported alkaline protease production is found to be higher at $\mathrm{pH} 9-13$ (Graph 1).

Graph.1 Effect of Incubation $\mathrm{pH}$ on protease production

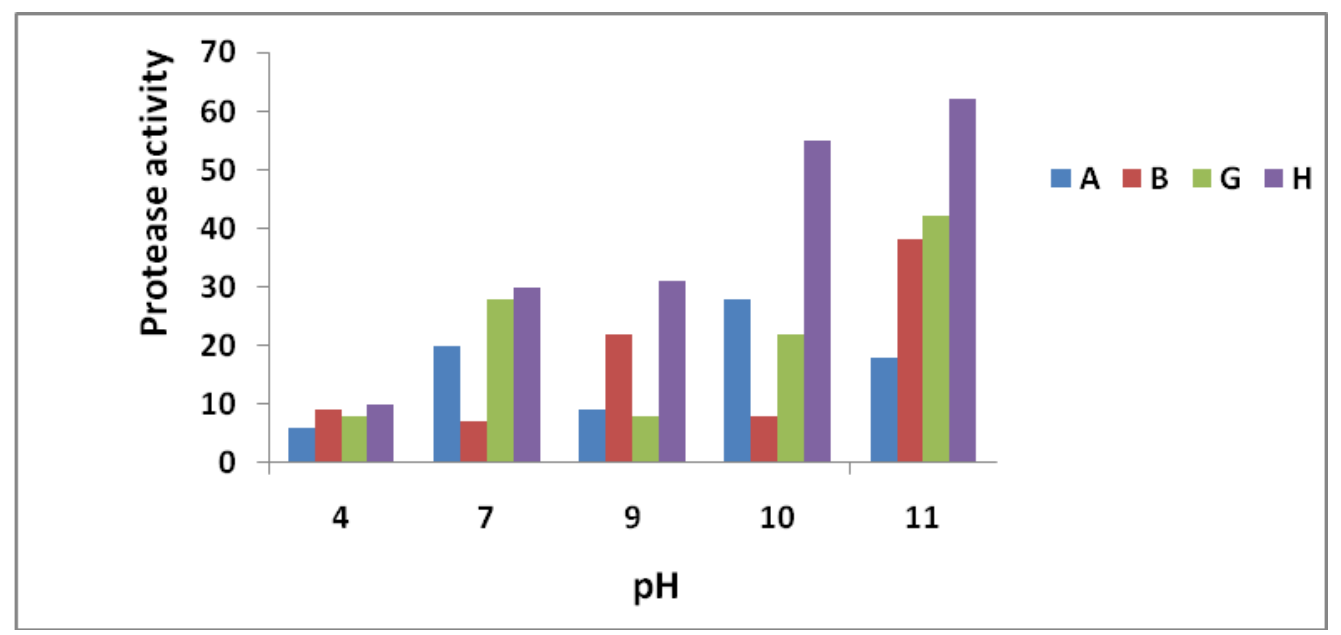

Graph.2 Effect of temperature on protease production

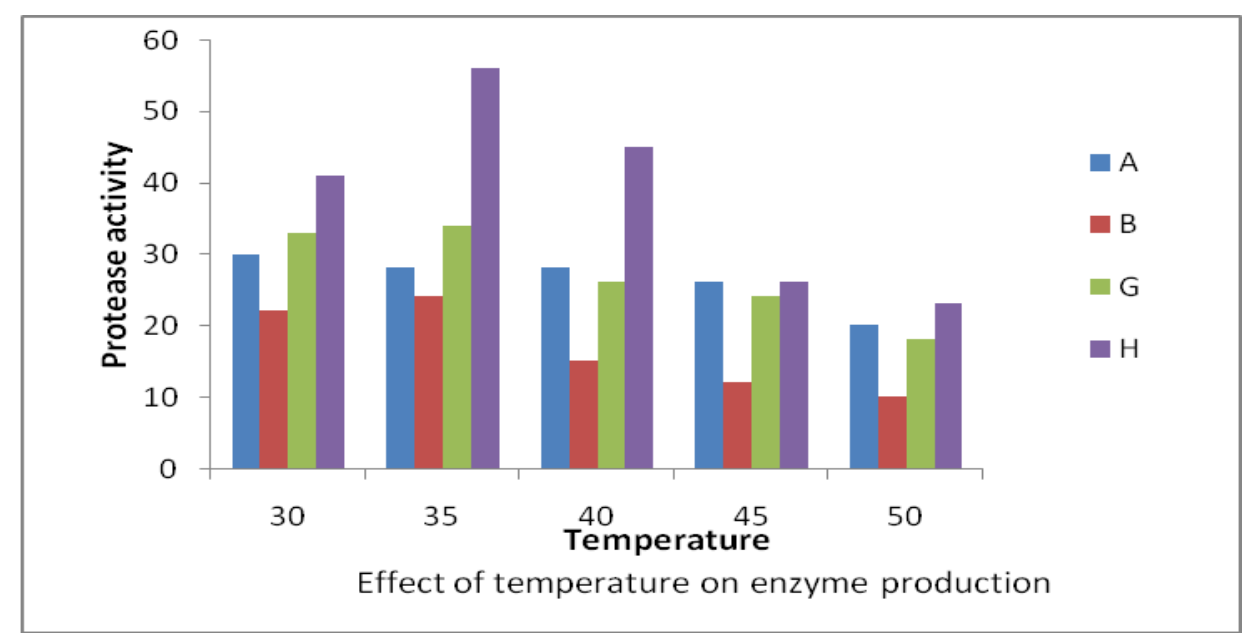


Graph.3 Effect of different carbon sources on protease production

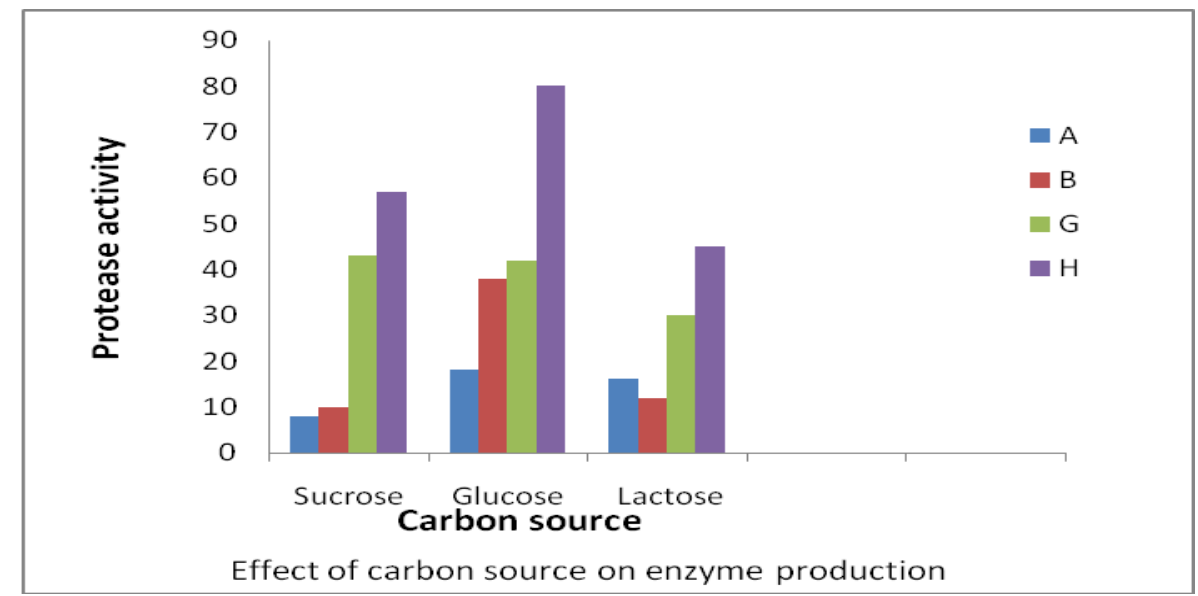

Graph.4 Effect of incubation period on protease production

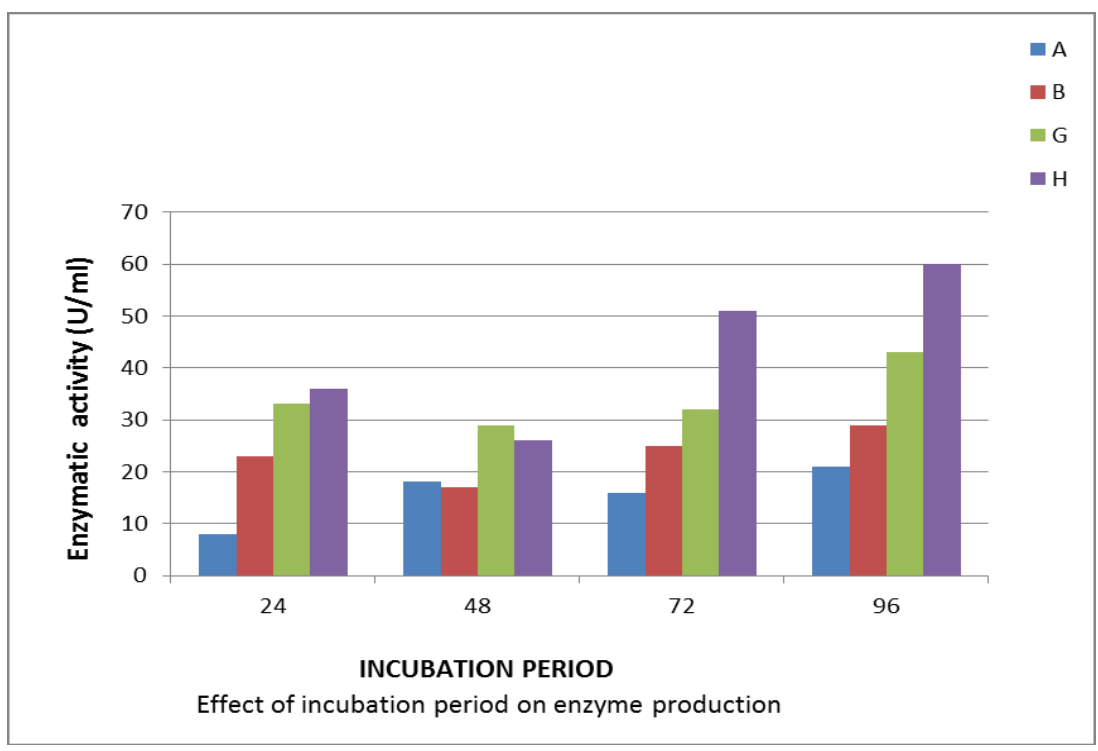

Fig.1 Isolate on PDA slant

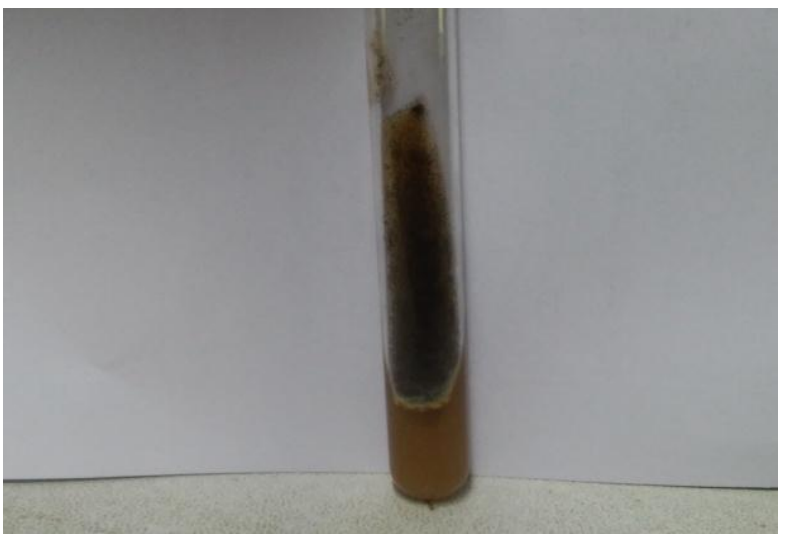

Fig.2 Microscopic image of the isolate

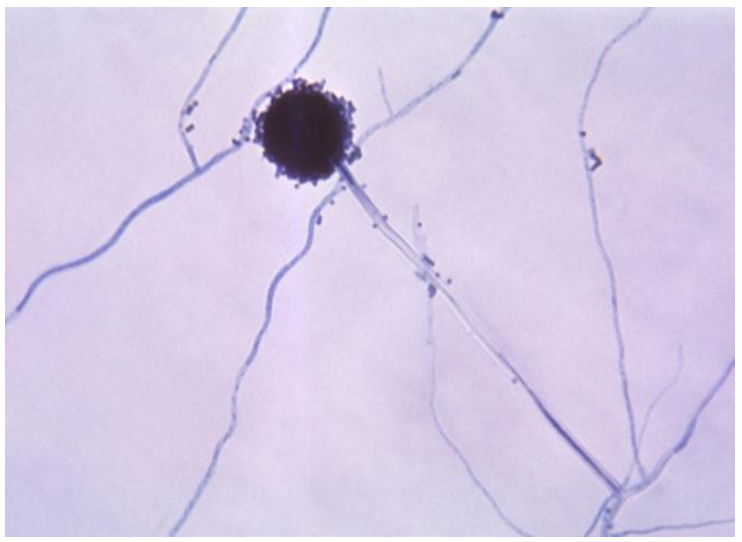


Effect of incubation temperature on protease production

Incubation temperature plays an important role in the metabolic activities of a microorganism. Even slight changes in temperature can affect enzymes production. Presently, the optimal temperature for maximum protease production was at $35^{\circ} \mathrm{C}$ by the fungal strain $\mathrm{H}$ with production decreasing at higher temperature. Since enzyme is a secondary metabolite produced during exponential growth phase, the incubation at high temperature could lead to poor growth and thus a reduction in enzyme yield (Sabu et al., 2012). Among the four fungal strains, A, G, $\mathrm{H}$ shows high protease activity at $350 \mathrm{C}$ and hence undergoes large scale production. Assay mixture was incubated at different temperature ranging from $30-60^{\circ} \mathrm{C}$ and enzyme activity was found to be highest at $35^{\circ} \mathrm{C}$. However, the enzyme was completely inactivated at $60^{\circ} \mathrm{C}$. The optimum temperature for protease production for by was in mesophilic fungi Synergistes species at $35^{\circ} \mathrm{C}$ (Graph: 2).

\section{Effect of different carbon source on protease production}

Various sources of carbon such as sucrose, lactose and glucose were used in optimization of production of protease enzyme. Results obtained showed that strain $\mathrm{H}$ in presence of glucose brought about the maximum protease production compared to other carbon sources (lactose and sucrose). After optimization of the effect of the carbon source for protease production, selected strains $\mathrm{A}, \mathrm{G}, \mathrm{H}$ shows high activity and hence undergoes large scale production of these strains at glucose as carbon source. There are general reports showing that different carbon sources have different influences on extracellular enzyme production by different strains (Nehra et al., 2002). The carbon sources like glucose, maltose, and starch were indispensable components for protease production by $S$. albidoflavus in submerged fermentation (Narayana et al., 2008). (Graph: 3)

\section{Effect of incubation period on enzyme production}

After optimizing the production parameters, fermentation was carried out under optimize conditions on shake flask. The amount of tyrosine liberated/g of substrate was found to be $63 \mathrm{U} / \mathrm{ml}$ (graph 1). So the maximum production of protease enzyme at the fourth day i.e, at $96 \mathrm{hr}$ of incubation, with other operate parameters remaining the same. After optimization of incubation period on enzyme production, the selected fungal strains $\mathrm{A}, \mathrm{H}$, $\mathrm{G}$ have high protease activity and so undergo large scale production of these strains at $96 \mathrm{hr}$ of incubation. The lower production could be due to increase in volume of the medium and lower aeration level (Graph: 4).

\section{Identification of isolate}

Ten different isolates are isolated, out of which one fungus with high protease production was selected and identified on the basis of morphological characteristics in National Fungal Culture Collection of India (NFCCI \& FIS) Pune as Aspergillus niger (Fig. 1 and 2).

In the present work, the protease producing strains are screened by casein hydrolysis and after optimization were done for the maximum protease production. The optimization parameters are $\mathrm{pH}$, incubation temperature, incubation period, carbon source etc. The most potent protease produced strain was identified based on morphological characterization characteristics in National Fungal Culture Collection of India (NFCCI \& FIS) Pune. The maximum enzyme production was at $35^{\circ} \mathrm{C}$ and at $\mathrm{pH} 11$. Glucose is the 
selected carbon source for protease production. The enzyme activity of protease is shown more in the $4^{\text {th }}$ day of batch fermentation. Thus the crude and partially purified enzyme was isolated and stored at $4^{0} \mathrm{C}$ for future use.

\section{Acknowledgement}

Authors are highly grateful to the CEPC Laboratory and Technical Division, Mundakkal, Kollam for allowing us to carry out such a noble work for pollution free environment.

\section{References}

Agarwal D, Patidar P, Banerjee T and Patil S. (2004). Production of alkaline protease by Penicillium sp. Under SSF conditions and its application to soy protein hydrolysis. Process Biochem., 39: 977-981

Anwar and Saleemuddin M. (1998). Alkaline proteases: a review. Bio resource Technology. 64: 175-183.

Borriss R Biology of enzymes. (1987). In: Biotechnology (Rehm H and Reed G. eds). Weinheim, Verlag chemie. pp. 3562

Cappuccino J.G, and N. Sherman. N. (2002), Microbiology: A laboratory manual. Pearson Education, 6(4), 21-23.

Demain AL, Adrio JL. (2008). Contributions of microorganisms to industrial biology. $\mathrm{Mol}$ Biotechnol. 38:41-5.

Ferid Abidi, Ferid Limam. (2008). Production of alkaline proteases by Botrytis cinerea using economic raw materials: Assay as biodetergent. Process Biochemistry, 43: 1202-1208.

Narayana K.J.P, Vijayalakshmi M. (2008). Production of Extracellular Protease by Streptomyces albidoflavus, Asian Journal of Biochemistry, 3(3): 198-202.
Nehra K.S., Dhillon S., Chaudhary K and Singh R. (2002). Production of alkaline protease by Aspergillus species under submerged and solid state fermentation. Ind.J. Microbiol, 42, 43-47.

Rao MB, Tanksale AM, Ghatge MS, Deshpande VV. (1998). Molecular and biotechnological aspects of microbial proteases. Microbiol Mol Biol Rev. 62: 597-635.

Sabu A, Sarita S, Pandey A, Bogar B, Szakacs $G$ and Socol C.R. (2012). Solid-State Fermentation for Production of Phytase by Rhizopus oligosporus. Apl Biochem Biotechnol., 103, 251-260.

Sharma J, Singh A, Kumar R, Mittal A. (2006). Partial purification of an alkaline protease from a new strain of Aspergillus oryzae AWT 20 and its enhanced stabilization in entrapped $\mathrm{Ca}$-alginate beads. Internet $\mathrm{J}$ Microbiol. 2(2):1-14.

Singh R et al., (2016). Microbial enzymes: industrial progress in $21 \mathrm{st}$ century. 3 Biotech, 6: 174.

Sookkheo, B., Sinchaikul, S., Phutrakul, S. and Chen, S.T. (2000). Purification and characterization of the highly thermostable proteases from Bacillus stearothermophilus TLS33. Prot. Exp. Pur., 20: 142- 151.

Souza PM et al., (2015). A biotechnology perspective of fungal proteases. Brazilian J Microbiol, 46: 337-346.

Ward OP. (2011). Proteases. In: Moo-Young M, editor. Comprehensive Biotechnology. 2nd edn. Waterloo; Canada. pp. 571-582

Zambare V et al., (2011). A novel extracellular protease from Pseudomonas aeruginosa MCM B-327: enzyme production and its partial characterization. New Biotechnol., 28: 173-181.

\section{How to cite this article:}

Parvathy G., C. Prabhakumari, Nair Sreecha Chandran and Sonia John. 2017. Optimization of a novel alkaline protease from Cashew Industrial soil associated Aspergillus niger. Int.J.Curr.Microbiol.App.Sci. 6(12): 3326-3332. doi: https://doi.org/10.20546/ijcmas.2017.612.387 